\title{
The Collapse of Bridewealth and its Impact on the Isukha Marital Institution, 1894-1945
}

\author{
Leen Kavulavu \\ Prisca J. Tanui Ph.D. \\ School of Arts \& Social Sciences \\ Department of History \\ Political Science \& Public Administration \\ Moi University
}

\begin{abstract}
This study examined the centrality of bridewealth payment in Isukha marriage before the establishment of colonial rule and missionaries activities. Bridewealth guaranteed stability in Isukha marriage. The study argues that colonialism was responsible for the changes that took place in Isukha marriage. In addition, Christianity impacted on marriage tastes and choices. To them bridewealth made marriage a mere mercantile transaction and they resolved to discourage the practice among baptized Christians as far as possible. In this effort however, they were not very successful for Christian continued to receive and give bridewealth, given the important symbolic role placed on it by the people of Isukha. What determined and shaped Isukha marriage bridewealth was the economic stresses suffered by the people when it came to using cattle to pay taxes. This meant a total loss of bridewealth. Methodology for this study involved data collected from secondary and primary data derived from archival and field research. This study findings argues that colonial and missionary penetration disrupted the social fabric which weaved and kept moral and responsible behaviours in marriage relations in a state of equilibrium. It did this in several ways, for instance through imparting western cultural attributes to the Isukha, in attempt to undermine their culture by targeting features such as bridewealth exchange. The consequences of this was gradual and systematic transformation of Isukha marriage.
\end{abstract}

Keywords: Bridewealth, Colonial rule, Christianity, Isukha, Marriage

\subsection{Introduction}

\subsection{Bride wealth among the Isukha in the Pre-colonial Period}

Bridewealth had an important social, economic and religious significance in Isukha marriage. Through bridewealth, a new relationship was formed between the families of the spouses. The union between the two families remained effective beyond the lifetime of the original individual spouses. The wider the family extends, the stronger the bonds of kinsmanship and the chances of social disintegration were lessened. Shorter observed that: "bridewealth was a real symbolic gift of exchange legalizing the children of the union, indemnifying the bride's family, stabilizing the marriage to a limited extent and propitiating the lineage spirit" (Shorter, 1950, p. 170-171). Through bridewealth, family alliances and contracts were made between the families of the bride and the groom. The relationship which was through bridewealth endured beyond the life time of the individual spouses. All children born of a marriage of this kind, belonged to the kinship group of the husband. That is why among the Isukha when bridewealth had been paid, in case of separation and divorce, a woman had no right to take the children with her (Oral Interview, Joseph Mahero, 27/12/2017). The wife also belonged to the clan. Consequently, when a husband died, the widow was inherited by the deceased's brother or close relative. The Isukha also believed that a marriage without payment of bridewealth was like cohabiting with a woman as a concubine. That is why a man had no claim over a woman unless he had paid bridewealth.

Isukha bridewealth was usually paid in the form of livestock. The average full bridewealth for the Isukha marriage was three to six heads of cattle, three goats and 12 hoes( E.A.Andrere, The Abaluyia Customary law relating to marriage and Inheritance, KNA: PC/NZA/3/3/2, 10). Only cattle were counted as bridewealth the other things such as beer, hoe and goats were not counted as part of bridewealth, but as gifts. Isukha culture portrayed goats as very mischievous and so they could run and join the cattle which were being taken away, as bridewealth. When this occurred, the goats were left to accompany the cattle, not as part of the bridewealth but as gifts. Bridewealth was the cornerstone of the Isukha marriage hence the rule "no bridewealth, no marriage". Isukha culture required that the bridewealth be paid before the wedding day. However, basing on the understanding between the contracting parties, part of the wealth could be paid and the remaining amount completed in bits while the couple were cohabiting. 
It was the father's duty to raise bridewealth for his son's first wife. In case the son later married extra-wives, a thing that was normal and welcomed, the man shouldered the whole burden of raising and paying the bridewealth alone. No one could come to his aid in such situations. In most cases, polygamous individuals were economically well off hence did not need other people's assistance to raise bridewealth. Bridewealth among the Isukha like in many African communities was motivated by noble and genuine necessity, rather than by reason of malicious profiteering. Bridewealth did not mean selling of the bride in the Isukha culture. The element of purchase was introduced as a result of the socio-economic changes taking place in all the communities. Mathu in his work defends the institution of bridewealth, in his view: "bridewealth was not a purchase but rather an expression through the gifts and ceremonies that accompanied it. It was not wife buying" (Mathu 1971). The most honourable thing the bridegroom could do was to give something to appease the bride's parents for dispensing with their daughter's presence and her service. Bridewealth was therefore a token of love and a sign of a lasting bond of friendship as well as recognition that the woman would be an asset to the husband's clan.

In case a woman died before bridewealth was paid, she was buried at her parent's home. However, if the husband insisted that his wife burial to be done at his home, then the husband had to pay full bridewealth. Bridewealth thus confirmed and sealed marriage for the latter could not be said to have taken place even if the couple were staying together, until fully paid. The bride whose people had received bridewealth felt honoured and respected. It secured the wife's place in the new home. This assertion is echoed by Ember and Ember who posit that: "the bridewealth did not reduce the woman to the position of a slave but rather gave her family prestige" (Ember, 1973, p. 317). The husband who had paid bridewealth was socially permitted to control the wife and her children as well. That is why the Isukha marriage implied an exchange between separate groups. One group "receiving" and the other one obtaining something in return for the woman who was handed over. Any slightest excuse like failing to properly cook for the bride's people when they paid her visit could cause marriage dissolution if bridewealth had not been paid. This meant that the stability of marriage depended on whether bridewealth had been paid or not. Bridewealth among the Isukha was a social obligation and had nothing to do with wife-buying. When a man died before completing the bridewealth, his sons were expected to finish the balance. Although the bride's people received the bridewealth, they still retained some rights over her. She had thus not been sold.

Bridewealth marked the transition of some rights from one group to another. The cattle which died immediately after being taken to the bride's people were replaced. Depending on whether the couple had children or not, bridewealth could also be refunded either in full or in part. The quality of the cattle paid was also considered. A bride's people could not be fooled by the quantity alone. To ensure, that "good cattle" were received the bride's father sent his brothers and his sons to go and be shown the actual cattle which the groom's people wished to bring The "bad cattle" were rejected even while still at the groom's home. Such cattle had to be replaced by "good ones." One of the participant stated that:

After the girl is accepted by the bridegroom's family, bridewealth negotiation was organized at the bride's home. On the day of negotiation the bridegroom's family would be accompanied with a sheep and foodstuff. The sheep was placed outside the bride's homestead. If an agreement was reached the bride's father would then allow the sheep inside his compound and some ritual were performed. Later the bride's relatives especially paternal aunt who were married would secretly investigate the bride groom's home (Oral Interview, Dinah Shilazi, 06/01/2018).

On the last day when bridewealth was taken to the bride 'to -be' home, the prospective bride could still change her mind at such a time and refuse the imminent marriage. She expressed her disproval of the marriage by trying to drive back the cattle paid. She could also not drink of the cattle milk. To evade her people's pressure, she ran away to a distant relative or simply eloped. Bridewealth was thus a very important in Isukha customary marriage. It was hard if not impossible to come across a marriage where nothing had been paid in form of bridewealth. Even poor individuals were assisted by the community in raising the bridewealth. No marriage could be allowed to proceed unless and until the bridewealth question had been settled. Once the issue of bridewealth had been settled, all was headed for nothing but the wedding.

\subsection{The Missionary Penetration and the Isukha Response to Marriage}

The Establishment of Christian missions in the area of study date back to 1894 when the Church Missionary Society (CMS) established a station at Nasuti in Busoga ( Barker,1950,p.25). After the establishment of imperial control and the completion of the railway from Mombasa to Uganda, mission activity increased. This was because communication with the outside world was possible, and official protection was available (Wipper, 1997, p.162). 
The American Friends African Mission (FAM), also known as the Quakers, opened their first station at Kaimosi in 1902 (Amatsimbi, 2009, p.36). The Roman Catholic, Mill Hill Mission (MHM) expanded from Uganda and founded their first station at Kisumu in 1903; from here they spread to Mumias (1904), Ojola (1904), and Kakamega (1906) (Burgman, 1990,p.4-5). Their expansion into western Kenya was prompted by the need to minister to their Ganda converts employed as porters on the railway or in the port at Kisumu. Indeed, by 1904 about 500 Baganda were living at Kisumu, and most of them were Christians with the rudiments of literacy (Lonsdale, 1964, p.193). The South African Compounds and Interior mission later called the American Church of God (COG) established themselves at Kima in Bunyore in 1905 while CMS established their station at Vihiga in the same year. In 1906, the CMS moved to Maseno (Shorter 1950,p.25-26).

The initial impetus for the early Christian penetration of Western Kenya, then, was provided by the need to counteract the Muslim presence. In the case of Isukha, however, such motivation did not exist because the Isukha had little contact with Muslims. The Christian missions in the area included mainly MHM of the Roman Catholics and FAM.

With the inception of FAM in Isukha there were at least three significant cultural conflicts. First, the gospel message whose core teaching was based on Jesus Christ was in conflict with local beliefs and practices. Second, was the attitude which the missionaries had towards African traditional values and beliefs. Third was the impact of these attitudes on the African converts and others. The FAM attacked some of the African institutions, such as marriage system and wife inheritance, it took a very firm stand on polygamy and adoption of monogamy became one of the acid tests for church membership. However, these were some of the African institutions that the Europeans did not understand. In a letter to the Chief Secretary, on the issue of marriages contracted in the "native reserves" in accordance with tribal laws and customs, the Provincial Commissioner (PC) of Nyanza stated as follows:

Amongst all the tribes polygamy is the rule. Mahari (Bridewealth) is in all cases the basis of contract. The mahari practically represents payment for the woman in her transfer from her father or brother to the man who takes away from the service of such father. The girl is practically a free agent provided the prospective husband is prepared to pay mahari demanded, but the tribal custom frequently prohibits marriage by girls to men of another distinct tribe (North Kavirondo District Annual Report, 31/3/1918KNA, $\mathrm{DC} / \mathrm{NN} / 1 / 1)$.

Bridewealth was one of the most misunderstood aspects of African marriage customs. It involved giving to the bride's parent's gifts in form of cattle, goats and beer. It was after this that the Africans regarded marriage completed. It also gave surety and stability to the marriage. This cultural activity shocked the missionaries a great deal. To the missionaries and other colonialists, the marriage process, particularly the exchange of bridewealth was like purchasing a wife for cash. They assumed that the Isukha considered a man's wife an indication of his wealth. Equally, they thought that the fathers valued their daughters for the bridewealth for which they will one-day fetch (Webourn 1956, p.40). This practice was extremely affected by the introduction of cash economy. For the missionaries, the Isukha bridewealth system was a mere mercantile transaction and resolved to discourage the practice. However, as observed by Andere, the missionaries in Isukha failed to recognize that marriage among the Isukha was a social affair. It was an arrangement involving not only the bride and the groom, but also both families of the bride and the bridegroom. The elders and the women from both families were fully involved in discussing marriage arrangements. There was always a transfer of wealth in the form of bridewealth from the parents of the bridegroom to the family of the bride. The bridewealth was given to different members of the family. For example, some a heifer was given to the mother of the girl, a heifer for the girl's maternal uncle a bull to be slaughtered for the elders of the clan and two heads of cattle to two of his brothers. Bridewealth acted as a guarantee that marriage would last. If divorce became inevitable then the wife's parents would return the bridewealth to the parents of the husband (Political records book for North Kavirondo, KNA DC/NN/3/2/21).

Both the colonial government and the missionaries had no hesitation in attacking the African marriage system. To their disgust, the African marriage system did not resemble Section 33 of the East African Marriage Ordinance of 1902. This Ordinance allowed for a "civilized" form of marriage under monogamous conditions between individuals married according to the native law and customs (Marriage Ordinance 1902 and matters under 1924-1926, KNA PC/NZA/3/28/1/1). While the Isukha marriage involved families of both the bride and the bridegroom who ensured that the couple stayed together and honoured their marriage contract, the Christian marriage emphasizes wide latitude of freedom of individual action (Ibid). 
Divorce in the Isukha society was something almost unheard of, since it was not a matter of individual decision but a clan affair. A woman could not be dismissed by her husband without the consent of his family (Political records book for North Kavirondo, KNA DC/NN/3/2/21). A man could marry as many wives as he could afford to maintain. Polygamy was considered an "economic investment" because the wife was seen as a potential child bearing member of the community, a matter of prestige and a status symbol. The practice of polygamy offended the very strict western Christian views about monogamy and was ranked high on the list of native customs to be deprecated. All efforts were made to eradicate it. FAM played a leading role in efforts to eradicate the practice in areas occupied by the Africans. Although the few converts discarded customary marriage contracts in favour of Christian marriages, some of them soon lapsed into polygamy and married other wives. The economic significance of women in labour provision and their social importance in procreation remained a major contributory factor to this trend (Native Marriages 1924-1926, KNA $\mathrm{PC} / \mathrm{NZA} / 3 / 28 / 4 / 1)$.

The missionaries however failed to see the profound aspect of the Isukha polygamous family relationships. As a consequence, they demanded; the registration of the first marriage not only to teach the indigenous communities that administration did not recognize polygamous contracts as valid according to the Protectorate Laws, but also to mean the protection of the first wife in any of the Protectorate Courts, as dissolution of such marriage could only be obtained by a man in a legal divorce (Marriage Ordinance 1902 and matter under, KNA PC/NZA/3/28/1/1). The PC of Nyanza further explained that marriage which was contracted in accordance with the native law and custom was not marriage according to the law of East African protectorate, and could not be made as such unless there was a legislation to allow its validity (Ibid). The impact that Catholic and FAM missionaries had on Isukha family system was alarming. It showed that the missionaries had not given the family system much thought. Wives in polygamous marriages were sent away by husbands who wanted to become Christians, but how about their children who were forced to leave with them? Most of these wives who had no alternative after being sent away by their husbands easily joined the African independent churches which did not discriminate against them. Some wives were sent back to their husbands after the husband had received baptism. In other cases some men became polygamists even after baptism (Oral Interview Elizabeth Wendo, 03/01/2018).

In Isukha some form of mobility to town had been noticed among these women. This practice resulted into several cases of bridewealth return. Section 13 of East African Ordinance together with the African Marriage Ordinance put the practice of polygamy in a precarious position (Kavirondo Marriages and Divorces 1935, KNA, PC/NZA/2/9/21). It required that, any native who failed to register his marriage with the provision of the ordinance was not liable to court assistance should any case be preferred. But if certain flexibility born of experience was evidence on the question of dowry and mixed marriages, no such tolerance was extended to practice that the missionaries called "inheritance of wives" (Strayer, 1978, p. 80). This was where a widow was to be taken as "a wife" of another male member of a husband's family, often his brother's death. In the case of a widow, she was automatically inherited by the younger brother or cousin of the deceased husband. This was a socially approved system of family organization in which a bereaved wife was taken care of and in which the children continued to be cared for by someone closer to them in terms of family relationship (Political records book for North Kavirondo, KNA DC/NN/3/2/21).

With the coming of the missionaries, the marriage institution, instead of offering social and economic support to widows, was a suggestion that women were in the same category as material possession. This was a point of tension which had to be solved if Africa was to come to terms with Christian West (Webourn, 1965, p. 122). The view of the colonial administration was captured when the PC of Nyanza responded that:

any native woman married in accordance to the Native Christian marriage and divorce ordinance, whether before or after the commencement of this ordinance, shall be deemed to have attained her majority on widowhood and shall not be bound to cohabit with the brother or any other person or to be at the disposal of such brother or other relative or other person, but she shall have the same right to support for herself and her children of such marriage from such brother or other relative as she would have had if she had not been married as aforesaid" (Kavirondo marriage and divorces, 1935, KNA, PC/NZA/2/9/21).

This was reinforced by the Native Christian Marriage Ordinance of 1904, relevant only to marriages of natives who professed Christian religion (Ibid). When it came to the practice of "widow inheritance", the ordinance depicted a total Christian view. It contented that the practice not only viewed widows as movable property but also represented such marriage as a mean by which a Christian woman and her children could pass into heathenism and thus be lost to the mission. 
Polygamy, wife inheritance and bridewealth exchange served a purpose as far as Isukha marriage was concerned. The missionary attempts to eradicate them resulted in the disintegration of traditional Isukha marriage pattern.

\subsection{Objective}

The specific objective of the study was to examine the colonial rule and missionaries attitude on Isukha bridewealth payment in the institution of marriage.

\subsection{Study Area}

The study was carried out in among the Isukha. The Isukha people are part of the patrilineal Luyia community who live within Kakamega County in Kenya. Administratively, Isukha is located in Shinyalu Sub-county that has six wards namely; Isukha North, Isukha South, Isukha East, Isukha West, Isukha Central and Murhanda. Agriculture is the main economic activity with $80 \%$ of the population involved in agriculture based activities of both subsistence farming and cash cropping of tea and sugarcane by small scale farmers. Isukha are famous in western Kenya for their isukuti dance and bullfighting. This is exhibited especially during initiation, funerals, weddings and ceremonies.

\subsection{Research Methodology}

This was a historical study, based on both primary and secondary sources. Primary sources included archival information and oral interview. The primary sources utilized were oral information gathered from the field as well as archival sources, which were accessed at Kenya National Archives (KNA) in Nairobi. The oral interviews were conducted based on prepared unstructured interview schedules. A total of 60 participants among the Isukha were interviewed. The participants were identified through purposive sampling and snowballing sampling procedures. Focussed Group Discussions (FGDs) were also used to gather additional information for the study. Participants were selected from cross-sections of the entire community in Shinyalu sub-county considering:

a) If the person was mentioned by either documentary or oral participants.

b) If the persons were recognized by local administrators and researcher.

c) Elderly people who were knowledgeable on matters of people's history.

Interviews were recorded by note taking and voice recording (with the consent of the participants). The voice recording information was later transcribed. Using interview schedule the researchers gathered data until adequate information was obtained. All the information were later scrutinized and subjected for analysis with a view to arrive at viable historical conclusions. Since there were possibility of some participants to exaggerate certain information, the researchers corroborated the information gathered from different participants so as to ascertain the truth. In addition, secondary information was used to support an analysis and discussion based on primary sources and in search of information relevant to the study. The library materials that were utilized to write this thesis included both published and unpublished work of both electronic and non electronic books, journals, newspapers and dissertations. These information were accessed in major libraries in Kenya namely: Moi University's Margaret Thatcher Library; University of Nairobi's Jomo Kenyatta Library; Kenyatta University Post Modern Library and Kenya National Library Services in Eldoret town were visited in search of the information relevant to the study. The secondary data gave various interpretation scholars had given on family and marriage not only in Kenya but also in Africa and other continents of the world.

Data analysis was done using qualitative data to describe in depth what was on the ground. Oral data collected from questionnaire was compared and contrasted. Once the primary data was organized it was cross-checked with documentary sources. Through description, comparison and interpretation as method of analytical discussion, conclusion from data were made in respective stages.

\subsection{Results and Discussion}

\subsection{Marriage relations: the Missionary activities and colonial administration in Isukha 1919-1945}

The missionary activities had unleashed attacks on several African institutions, such as bridewealth exchange, polygamy and widow "inheritance". This time, some of the impacts of these attacks were realized in Isukha on a larger scale. These institutions were further weakened by the colonial administration considering payment of taxes and forced communal labour. The case of bridewealth exchange as had been explained was very problematic to the missionaries. To them bridewealth made marriage a mere mercantile transaction and in 1907 the mission resolved to discourage the practice among baptized Christians as far as possible. In this effort, however they were not very successful for the Christians continued to give and receive bridewealth, given the important symbolic role placed on it by the people of Isukha and other Luyia communities. Immediately after the World War I, problems arose in terms of bridewealth exchange. This was due to economic stresses suffered by the people of Isukha when it came to using their cattle to pay taxes. After the war taxes were in most cases paid in cash as most people in Isukha had reduced stock. 
A number of migrant labour who had gone to work with hope of raising bridewealth were disappointed as they realized that their wages could not adequately sustain their needs, leave alone the needs of their families back at home. The exchange of bridewealth involving cattle became a problem as the "big men" refused to relent on the rates. Some kept on confining their daughters until some exchange took place.

By 1924 this mounting pressure reached the Local Native Council (LNC) in North Nyanza. A debate ensued on what came to be called bridewealth stabilization or "reduction of dowry". The minutes of the Luyia Council, the mouthpiece of the Luyia community on matters affecting them, was also very particular on this. It decided that five heads of cattle were a sufficient "dowry" but the bridegroom was also to provide one bull for slaughter at the marriage feast (North Kavirondo District Local Native Council Expenditure Estimates, 1930, KNA,PC/NZA/3/33/8/9). Another issue that came up for discussion in the LNC was concerning marriage of premature girls. These were girls who had not reached fifteen years of age but would often be married to old men. It was difficult to come up with a conclusive explanation about the origin of the practice. In a letter to the District Commissioner (DC) Kakamega the office of the PC referring to this practice noted that:

This practice had become common among the Kavirondo for the avaricious parents to sell or marry off their very young and immature daughters in marriage. 1 would be glad if the DC would discuss with their LNC the advisability of passing a by-law making it an offense for a man to marry his daughter until she has reached the age of 14 or 15 . It would be a great thing too if the marriage price could be stabilized and would probably prevent an enormous amount of litigation. I am advised that one cannot make it an offense to pay a large price for a wife but it might be possible to achieve the same result by the various councils of elders refusing to allow a man to recover more than a certain minimum of stock, no matter what he had paid (Native Marriages 1926-1928 KNA, PC/NZA/3/28/4/1).

Why would parents give their daughters as young as fourteen for marriage? It seems that, the remarkable fall on bridewealth exchange had caused a lot of panic to many parents such that giving away a daughter for marriage at any exchange value could suffice. This notwithstanding, moral values had collapsed considerably in Isukha. The issue of banning all forms of western European dances wherein the participants had bodily contact throughout the dance also arose. This was on suspicious that they were responsible for the rising immorality. They were suggested to be harmful to the local "natives" because they resulted in promiscuous sexual intercourse, loss of bridewealth, lowering standards, unwanted children, murder, seduction, adultery, among other things (Political Records book for North Kavirondo, KNA, DC/NN/3/2/21). In these dances girls could elope with no bridewealth exchange. This may have influenced many girls and parents to admire entry into marriage even at a limited bridewealth exchange.

Capitalist penetration into Isukha during this period was also remarkable. Its results could not be avoided. Bridewealth totally collapsed. It was not what was traditionally accepted. Bridewealth started serving capital. Before the onslaught of capitalism, the bridegrooms' families, and in this way tangible relationships between different kinship groups, were established. Cattle were exchanged for women, though before the penetration of capitalism neither was regarded as merchandise. They had a use value but not an exchange value, because cattle were not traditionally offered for sale in the market. Cattle in Isukha provided people with meat and milk. Cattle in marriage legitimized children and guaranteed marriage stability. The return of bridewealth in many cases posed difficulties to many families. Bridewealth was generally transferred soon after it had been received for marriage of junior members of the woman's kinship. But if no man intended to marry at the time, the cattle were divided among the elder relatives in kinship who may transfer them for marriage of the juniors. Thus, parents put pressure on their daughters to stay with their husband unless it was quite clear that the husband had grossly transgressed the limits of their authority and therefore lost the right to claim their cattle.

The entrenchment of capitalism in Isukha brought about the most important changes which occurred in the bridewealth system. The money used basically to acquire almost everything acquainted the people with new forms of property and totally transformed pre-capitalist societies. The transformation of bridewealth system into commercial transaction is a natural consequence of these changes. Cattle payment began to be replaced partially by cash payments. Whereas in the past women were exchanged for cattle which had use-value, with capitalist entrenchment, women were exchanged for money, a medium of exchange which had occurred whenever marriage payment had been used for purpose other than obtaining wives in exchange for sisters or daughters (Okuro, 2002, p.127). Cattle used for marriage purposes were kin's properties and intended for the perpetuation of the kin. This time, the big men were unfortunate. They lost relevance as cattle ceased to be the most important factor in marriage "transaction". 
The few lucky men who could use their earnings to buy cattle, further, realized that they could also negotiate for the girl with the parents not the kin elders or elope with the girl. This meant a total loss of bridewealth. Taxation, cattle diseases, and the difficulty in eating daily needs reduced people's livestock and so hastened the replacement of bridewealth exchange in cattle with money. This did not mean that cattle were not used at all in marriage negotiations but the number of cattle exchanged greatly reduced. By implication, therefore, some unscrupulous fathers or parents could give out young daughters in marriage after receiving little tokens in form of money in order to cut other kin members from the bridewealth negotiations and use this for tax obligations among other pressing needs. This kind of negotiation affected many marriages as many girls started complaining that they were being forced to marry against their wish and to men they did not love. This was something the missionaries had previously spoken against with a hope of abolishing. Earlier in Feb 1927 the LNC had resolved without much success that it was an offense for anyone to allow their daughter to be married until she was fifteen years of age. The punishment in Baraza for such an offence was to be a fine of Shs 150 with three months rigorous imprisonment in default" (Establishment of Trade centres, 1928, KNAPC/NZA/3/33/8/25)

As the problem escalated the Chief Native Commissioner, G.V.Maxwell asked to be briefed on the whole issue of bridewealth stabilization which was debated in the LNCs. In his report, the senior Commissioner of Nyanza reported that young men were in favour of decreased marriage price since it prevented many young men from getting married leading to a lot of immorality. In the same period, the position of widows became problematic. This was especially concerning the widows who had refused to conform to traditional customs (Ibid). In July 1927 the senior commissioner made his position clear as pertains to Christian widows. He stated that "the position in regard to Christian widows in my opinion is that they are in a position to marry whom they please under the East African Marriage Ordinance" (Ibid). The PC on May $4^{\text {th }} 1915$ had reinforced the proposal by passing a resolution that:

A widow can go to another man and be married on the payment of the usual marriage price as time goes on such cases as you report will undoubtedly become more common, and it is very possible that an increasing number of women who are married to the more civilized class of the natives may, on becoming widows, object to conforming to native law and customs and will want to follow their own wishes it is, therefore, evident that the elders themselves should be instructed (educated) to the extent of their endeavouring to provide the local remedy i.e. be prepared to allow that the native law on this point shall be reconsidered and a rule be made that widows may when they so wish be allowed to re-marry without there being any question of the possibility of prevention on the part of the head of her late husband's family provided the marriage price is forthcoming (Political records book for North Kavirondo, KNA DC/NN/3/2).

These seemed to have freed the widows a great deal from traditional obligations that required the elders to get for them suitors. This freedom culminated in their mobility to townships, particularly Kakamega in the Isukha case in search for jobs and trading opportunities. To make things even more difficult in Isukha, officials turned their attention to Kakamega gold mining which required labour. In 1933 the principal labour inspector noted all the labourers employed on the gold fields were natives of North Kavirondo District, as the local administration did not authorize the employment of labour from any other reserve. The natives were mostly of the Kakamega (Isukha and Idakho), Tiriki, Maragoli and Watsotso tribes (Labour employment of servant mines labour 1933-47," KNA, DC/KMG/1/9/8).

The economic depression of the 1930s worsened the issue of bridewealth payment. It surfaced very strongly in the 1930s during LNC meetings in Marenyo. Under the title "stabilization of marriage price", it was suggested that bridewealth price was to be fixed in all locations at five heads of cattle, one bull and one goat (Correspondences 1930, $\mathrm{KNA}, \mathrm{PC} / \mathrm{NZA} / 4 / 1 / 1 / 1)$. It was supported by the argument that "several young men were unable to obtain wives as a result of lack of cows and there was a tendency to run away with girls to farms in the coast. The girls were in favour of the reduction of "Mahari" (bridewealth) ( Local Native Council General 1927, KNA PC/NZA/3/33/8/25). On bridewealth stabilization, the report noted young men certainly complained that they could not collect enough property to obtain a wife. It was also true that rich old men collected young wives. (General Native Policy 1944, KNA, $\mathrm{PC} / \mathrm{NZA} / 3 / 1 / 1)$. The fact that girls were in favour of a reduction of bridewealth gives a very problematic suggestion. It seems that the big men were holding on them against their wish. Either they wanted to join the trail of labour migrants or they wanted to get married. The former preposition looked attractive because famine had strongly hit the localities without much remedy from the colonial administration. Coupled with the need to assist in acquiring money to pay taxes, the search for wage labour seemed attractive. 
Among the Isukha women who had been forced into marriages without their consent felt cheated. They started rejecting these marriages by running away. The issue of run-away wives thus became much prevalent during this period. While every woman had her own reasons for refusing marriage during this period, several explanations can be put forward to explain the situation. Some fathers could force their daughters from marriages under the contention that not enough bridewealth had been given. Even more pressing on the part of the women was the demand to be "clothed". A tussle only was not important as a husband who could not provide clothes for a woman risked the woman running away. In the 1930s, men felt they lost control over women in dresses and the elders felt they lost young men who were now in shirts and trousers (Oral Interview, Peter Lubelela, 02/01/2018). The colonial administration had introduced taxation, forced communal labour, and male labour conscription. All social and economic security system had collapsed, exposing men and women to any eventuality. Women had learnt a lesson from men. The women particularly those referred to as "independent women" started seeking for wages to feed their children or ran away from not only commitments of tax but also traditional obligation. According to one of the participants, "it was the position of women that was changing. This was due to their encounter with new novelties. According to the participant: They were nolonger porters; the bridegroom now had to buy her cloths instead of presenting her with marriage tail. On stabilization of bridewealth she observed that it cut both ways if the elders received fewer cattle for mahari; they had to assist their sons with fewer animals (Oral Interview, Lena Khakhuya, 25/12/2017). The participant explained this phenomenon in terms of the difficulty arising from advancement of education and communication which had brought about partial breakdown of traditional customs. She said that women were not easily forced to cohabit with men they disliked. This was however the case of the seducer who was able to pay bridewealth and who enticed away-married women. She even blamed the colonial government for it lacked any drastic measure to deal with the problem.

Between 1930 and 1935 the question of bridewealth stabilization reached the church. Previously, bridewealth exchange was one of the most emotional issues between the Luyia communities and the incoming Christian missionaries. The policy was to convert the local people. This meant making frontal attacks on the beliefs, the customs, the apprehensions of life and the world, and by implication on the social structures and bases of "primitive" society. However, when it came to bridewealth the Christian missionaries did not seem to be very successful for converts continued to receive bridewealth in Isukha. When the issue of bridewealth came up in the meeting of the LNC, the missionary representative had no hesitation but to blame it on failure in instituting voluntary registration of marriages and advocation of compulsory registration of marriages (North Kavirondo District Local Native Council Estimates 1930 KNA, PC/NZA/3/33/8/9). Archdeacon Owen in 1936 also considered registration of marriages on the same ground. He said that "the chief purpose of compulsory registration was that no marriage should be compelled if the girl refused and although at first she might not have the courage to do so when she could soon gain it" (Correspondences 1938,KNA,PC/NZA/2/1/104). While the DC of North Nyanza argued that registration of marriage be made compulsory and would be beneficial to the district within the colonial administration docket would ultimately cause the whole bridewealth system to break (Kavirondo Marriages and Divorces 1935, (KNA, PC/NZA/2/9/21). The committee of Native Marriage and Divorce that met in Nairobi recommended that in all marriage transaction the cash value of stock should be fixed by law. Approximate value as follows:

$\begin{array}{ll}\text { Cow } & 120 /=\text { to } 150 /= \\ \text { Heifer } & 100 /= \\ \text { Bull } & 50 /=\text { to } 60 /= \\ \text { Bullock } & 120 /=\text { to } 130 /= \\ \text { Sheep } & 10 /=\text { to } 15 /= \\ \text { Goat } & 15 /=\text { to } 20 /=\end{array}$

Source: KNA, PC/NZA/3/28/4/1 NATIVE MARRIAGES

Nevertheless, the impact of Christianity during this period was not that remarkable, considering the number of celebrated marriages. The total numbers of Christian celebrated marriages at Roman Catholic and FAM all within the vicinity of Isukha were shocking. The Nyanza Province annual report of 1934 to 1938 indicated that a total of about 4539 Christian marriages were celebrated. In 1936 the Nyanza PC tabled the missionary suggestion of compulsory registration of marriage to the colonial secretary. In support of compulsory registration of marriages, the PC recommended that

With the increasing emancipation of men and women, tribal authority has broken down their sanction of parents and fathers. Native tribunals find at every turn that they are unable to enforce the old law and there are limits to the extent to which government is willing to support them. In consequence girls too complain when they are forced to marry against their will; lovers begin to set up house together without exchanging bridewealth, the wives 
begin to desert from the husbands whom they never chose or of whom they are tired of. We are dealing with a stage where family group system is decaying while a fully individualized system has not yet come into being a compulsory marriage register is recommended principally to prevent forced marriages but also because it will be valuable as a record ( Marriages 1935, KNA,PC/NZA/2/9/21).

It should however be noted that the issue of whether to adopt a voluntary or compulsory marriage registration still remained unresolved almost throughout the colonial period. As one participant reported in support of the PC's recommendations detailing the extent to which social transformation had taken place on the whole process of marriages in Isukha. He noted that:

There were no cases of forced marriage to my knowledge nowadays. In the past the customs was for an arrangement to be made between the father of the bride and the bridegroom to be. It was then possible for the father of the girl to enforce the marriage. This does not happen today. What happens is that an arrangement is first made between the man and the girl. They meet at dances and take a fancy to each other. They then go to the father of the girl and the matter of the bride price is settled and preliminary payment made. After this the father of the girl can force her to keep her promise to the man of her choice (Oral Interview Joseph Mahero, 27/12/2017).

With regard to social transformation, the number of women referred to as "independent" increased tremendously as the WWII approached (Native Taxation 1938, KNA, PC/NZA/3/10/153). Due to various reasons the women had started drifting in large numbers into the emerging townships, such as Kakamega whose growth was explained in terms of mining and African development. But towards 1938, the PCs were forced to review and come up with some recommendations on how the issue would be passed and operationalized to "native" girls and women entering Municipalities and Townships. They observed that the DCs had envisaged the necessity and the urgency of control. They recognized and appreciated those responsible "natives", parents and elders in the "reserves" who were perturbed by the situation and would welcome control. The PCs without hesitation endorsed the recommendation of the subcommittee of the DC' meeting of $22^{\text {nd }}$ March, 1938, Minute No. 20, and recommend that the Native Pass Laws be amended as proposed namely:

That no female native whose lawful guardian is normally resident in the native reserve shall, except within the boundaries of such native reserve, or municipality or township, travel or be transported by any motor vehicle as defined under the Traffic Ordinance No.26 of 1928 , unless she shall be in a possession of a pass duly authorizing her to do so, endorsed by such guardian and issued by a district officer, or other duly authorized agent stating the points between which such pass is valid and the period of such validity. Any such female so travelling and any person so transporting any such female shall on conviction be liable to a penalty on default (Correspondences 1938, KNA, PC/NZA/2/1/10) .

Men including clan elders and family heads, could not raise bridewealth for their sons nor were sons able to raise adequate cattle for the same. They tried successfully to enter individualized negotiation as girls became difficult to tame using traditional obligations and customs. Capitalist goods and luxuries in towns had lured many girls and women either within the localities or in townships. Women could only enter into marriage to men who could offer them these luxuries. The tribal authority was under transformation. The colonial administration on the other side drove able men out of the localities. It should be observed that starvation, forced labour, famine and taxation became the only words to describe localities of Isukha during this period. To the men, time was ripe for putting something in place to control women's mobility. The standard of living in Isukha dropped women and young men who were not seriously or part of family production unit became increasingly vulnerable. Many who lost their sources of livelihood were forced by circumstances into the urban areas to seek for cash to fend for themselves.

\subsection{The Impact of the Christian Church on Isukha Marriage}

It is worth mentioning that most early converts were included even encouraged by missionaries to stay in or around the mission stations while the non-converts remained in their homestead. This idea of dissociating from one's family or 
community that was not Christian made one to become an individual within the community and this was something that had never been heard in Isukha land. Isukha people lead a corporate life all through. As a consequence, this individual lost the community guilt conscience and hence adopted new values. Furthermore, in these mission stations it was no longer possible for the members of the extended family to discharge their duty of instructing their pre-initiated and initiated boys and girls on matters of sex, especially what was expected of them in their marital life. As a result, the children grew up completely ignorant of their sexual life (Oral Interview, Edward Konzolo, 16/01/2018). Further, the missionaries set up schools based on western standards. For those who desired to be enrolled, a change of religion was a prerequisite since school and churches were intertwined. In the missionary schools no education was given on African customs governing the obligation of an individual to relatives within and outside immediate family circles. Education on ceremonial rites in which kinship obligation were expressed and observed was ignored. It was demanded that no student should be seen observing or participating in those ceremonies. Students having been introduced to catechism and having been taught about the evils of their customs, they were made to believe that their own parents and community at large had nothing to offer them because they were pagans and hence their counseling, and teaching on matters of marriage was greatly checked (Oral Interview, Peter Lubelela, 02/01/2018). The consequence of this state of affair was that many youths were uprooted from their cultural roots. An Isukha who desired to marry and had gone through a missionary school did not seek advice from his/her members of the extended family for they had been taught to believe that their customs were oppressive and tyrannical and that adhering to them was cumbersome, non-Christian, improper and militating against their freedom. Mostly, affected customs included those taboos that had to do with checking the indulgence in sex among the youth and such were termed as sheer superstitions. Such individuals were encouraged to undergo sacramental rites that prepared them for a westernized form of marriage.

As already noted, initiation rites were among the most important valued process in preparation to marriage. But unfortunately, the missionaries made little or no attempt to use them. The acceptance of Christian faith by Isukha was accompanied by a similar acceptance and accommodation of western values. For instance, FAM undertook to circumcise boys, an operation which in no way satisfied the initiation requirements of Isukha culture. Thus, those who converted were under spiritual obligation to avoid initiation rites accompanying Isukha circumcision. Customarily, during the circumcision rites the members of the extended family and the clan at large played a major role in counseling the initiates on what entailed marital life. Thus, the parents and the community at large, were in a position to influence decisively, the nature and form of marriage through the practice of circumcision. Moreover, circumcision was a prerequisite to marriage and was done to young men of 20-25 years who were almost approaching age of marriage. With the teaching of Christianity circumcision was done in hospital at a tender age. It also altered marriage education that used to be given to boys. Boys circumcised in hospital were looked down upon as "lesser" men and missed out on marriage education which accompanied circumcision.

The missionaries initiated the freedom of choice of one marriage partner by another and recognition that the choice was to be based on love, personal attraction and Christian commitment. Makobe Mikadi vividly brought this out in a letter written to the DC North Nyanza stating that marriage did not mean somebody's property, action was to be taken to parents who forced their daughter to the parent's choice (Native Tribal laws and customs and dowries 1955-58, KNA, $\mathrm{DC} / \mathrm{KMG} / 1 / 1 / 152$ ). The role of parents and other members of the extended family concerning choice of marriage partner had been seriously eroded in the decolonization period in this choice. Besides, the missionaries emphasized that the consent was for the two people, the spouses to be. The community idea was there, but not much emphasized in terms of being asked about the consent. In the long run the idea of family involvement in the negotiations was systematically discouraged as this was interpreted as a hindrance to the freedom of boys and girls, going against their "God" given right to choose for themselves. In short, the communal aspect of choosing a partner was forced to give way to the individual aspect.

It is also interesting to note that during this period of decolonization, many Isukha men and women had been converted into Christianity and missionaries did not bother with the intricacies of bridewealth in Isukha marriage. They saw in it only what they believed to be a business transaction. They did not hesitate to condemn all the ceremonies that accompanied it such as the feasting and activities that were involved such as pouring of libation to ancestors among others as unchristian. Consequently, these men were not prepared to regard it as a significant factor for the validity of marriage as was the case in Isukha marriage. Instead, they based the validity of church marriage on the ring, on the vows observed on the wedding day and the documents signed in the presence of the witnesses namely the best man, the best maid and the priest. As a result, the approval of the marriage by the parents of both sides and their respective clans was ignored. It is then not a wonder that in the church marriage vows are promises of a husband to his wife and of the wife to her husband that hence forth they are going to live in harmony helping each other to maintain a stable marriage. Furthermore, those who were already married when the missionaries came and wanted to join the church had to live their marriages solemnized before they were considered for full membership. This was true because the missionaries 
found the Isukha marriage "wanting" and thus proceeded to standardize it so as to conform to their western view of Christian marriage.

The church brought forth the idea that marriage was a contract between two people, man and a woman. They taught that love could only be shared between two people and that the essence of marriage was to become one flesh with the other partner and that the idea of marrying more than one wife negates these two factors. Thus, they emphasized and even made it compulsory for the converts to enter into monogamous marriages. They also laid emphasis on nuclear family and the fact that the two newly married partners had an equal status in their new home. If a polygamist wished to join a church he could neither be baptized nor be a communicant let alone having his marriage solemnized unless he got rid of all except one wife preferably the first wife. Similarly, a woman who was married to a polygamist could not become a full member of the church. If she wanted to be baptized she had to leave her husband. In accordance to the new faith a husband was to remain faithful to one wife and had to denounce many of his customary values, such as the opportunity to have a large family by having more than one wife. Besides, the missionaries introduced a new change in the Isukha conception of the purpose of marriage. Among the Isukha, procreation of children was the very purpose of a marriage and sexual intercourse was its very essence. The missionaries taught that marriage was an institution with a higher value. That it was a creation from God with the help of whom man could reach eternal salvation. They asserted that procreation was not the only important factor since children were a blessing from God and that companionship, that is, life-long partnership, help and comfort which a husband and a wife ought to have of each other, holds a higher goal in marriage and hence the issue of children was a secondary one.

Thus, according to the new values brought about by missionaries a childless marriage could remain happy and valid marriage for as long as there was conjugal love and total commitment to each other (Karanja, 1998, p.108). As noted, among the Isukha a childless marriage was a total failure and all ways and means were employed to rectify this predicament. This is because marriage was viewed as the gateway to life, hence infertility and sterility blocked the channel through which the stream of life flowed and the victims were thus plunged into misery. The missionaries were totally against any form of divorce. This implied that the marriage contract could not be broken at will or with the consent of the contracting parties but only through death of one of the parties. Notwithstanding, they went further and introduced a foreign reason for divorce namely that "if sexual intercourse does not take place soon after marriage, the marriage become void and useless". Thus, unlike the case of Isukha marriage, impotence of the husband became an adequate reason on itself to an null a marriage (Oral Interview, Peter Lubelela, 02/01/2018). According to the church, it was only by sexual intercourse that the marrying couple became one flesh, which was the essence of sacramental marriage. Each partner therefore fulfilled the marital obligation in sexual union.

As already discussed, the missionaries brought about the notion of marriage being a contract between two people and hence the death of one partner meant the end of the marriage. As a result, caring of the widow's sexual and procreation needs especially if she had no children with her husband within the family in which she was married was condemned and ruled out among the converts to the new faith. Furthermore, the widow was not supposed to have more children and if she did so, unless she had remarried in church, she was supposed to stop receiving church sacraments in the case of the Catholic and leadership position within FAM. The missionaries also brought about the idea that one could choose to lead a celibate life either as a sister, brother, Christian lay person or as a priest for the glory of God and the service of the wider community. In whichever way, the missionaries emphasized that single state was a vocation worth equal respect just as marriage was. In Isukha, marriage was between a mature woman and man. Marriage was a vocation and duty for all normal persons and those who married enjoyed a higher status in Isukha society. Apart from the impact of the church on Isukha marriage, something else was to happen within the administrative sphere in the postwar period which, as time progressed impacted strongly on Isukha marriage.

\subsection{Conclusion}

The overall impact of the establishment of colonial rule among the Isukha was that it created incentives which discouraged polygamy, especially among the generation which was born after the establishment of colonial rule. In particularly, the introduction of hut tax placed a lot of demands on young men to migrate from their homes. The wages which they earned were insufficient to enable them bring up children, let alone pay bridewealth for numerous wives. The introduction of monetary economy also led to the gradual decline of livestock as a currency with which to pay bridewealth. Livestock also became a commodity which was to be sold. The conversion of Isukha into Christianity gradually led to Christian marriage preference. Many men shifted from polygamy. The overall impact was the individualization of decision making concerning marriage matters. Marriage, prior to the establishment of colonial rule among the Isukha was a communal affair.

Fathers assisted their sons to pay bridewealth, aunts assisted their nephews to find a bride. This changed when the church started playing a role. Evident also in the study was the extent to which socio-economic and cultural structures 
collapsed. The collapse witnessed new structures emerging to control family and marriage relationships, especially to those women who were responding to stresses caused by the colonial administration in the "native" area of Isukha. The colonial administration, through its mechanisms such as taxation, communal labour, male labour migration, poor wages, saw rampant collapse of marriages, bridewealth system and morality transformed the traditional Isukha culture and economy. Bridewealth exchange also witnessed a downward trend. Bridewealth exchange no longer depended on collective arrangement of the clan but on individual arrangements. The experience of widows was equally not favourable as their belongings were not spared during taxation so long as they had hut, this demands affected African families, particularly married ones.

\section{References}

Amatsimbi, M. Herbert (2009), The Friends church and Economic Transformation Among the Luyia of Western Kenya, 1902-1988. D.Phil Thesis, University of Nairobi.

Burgman Hans (1990), The way the Catholic church started in western Kenya. London: Mission Book Service.

Ember Carol, R. \& Ember Melvin (1973).Anthropology.New York: Appleton Century Crafts.

Karanja James Mwangi (1998),An assessment of the interaction between Kikuyu customary marriage and Roman Catholic church marriage:The case of Tuthu Parish in Murang'a District. MA. Thesis, University of Nairobi.Retrieved fromhttp://erepository.unobi.ac.ke

KNA: DC/NN/3/2 21; Political record Book for North Kavirondo.

KNA:PC/NZA/1/8; Nyanza Province Annual Report, 3/31/1913.

KNA: DC/NN/1/1; North Kavirondo District Annual Report, 31/3/1918.

KNA: DC/NN/1/4; North Kavirondo District Annual Reports, 1923.

KNA: PC/NZA/3/28/1/1; Marriage Ordinance 1902 and matters under, 1924-1926.

KNA: PC/NZA/3/28/6; Marriage returns, 1925-1929.

KNA: PC/NZA/3/28/4/1; Native Marriages, 1926-1928.

KNA: PC/NZA/3/33/8/25; Local Native Council General, 1927

KNA: PC/NZA/3/33/8/25; Establishment of Trade centres, 1928.

KNA:PC/NZA/3/33/8/9; North Kavirondo District Local Native Council Estimates, 1930.

KNA: PC/NZA/3/10/170; Hut and Poll Tax Collection, 1932-46.

KNA: DC/KMG/1/9/8; Labour employment of servants mines labour, 1933-47.

KNA: PC/NZA/2/9/21; Kavirondo Marriages and Divorces, 1935.

KNA: PC/NZA/2/9/21; Marriages, 1935

KNA: PC/NZA/2/1/104; Correspondences, 1938.

KNA: PC/NZA/3/10/153; Native Taxation, 1938.

KNA: PC/NZA/3/1/1; General Native Policy, 1944.

KNA: PC/NZA/3/15/88; African men, 1945.

KNA: DC/KMGA/1/60/60; Law and Order Offences policy, 1945-1961.

KNA: PC/NZA/3/15/85; Native Land Tenure, 1946.

KNA: DC/KMG/1/1/152; Native tribal laws and customs and dowries, 1955-1958

KNA: DC/KMG/1/1/181; General Correspondence on Maendeleo ya wanawake, 1959-60

Lonsdale J.M. (1964) A Political History of Nyanza, 1883-1945. Ph.D. Thesis, Trinity College Cambridge.

Mathu,W. George (1971),Gikuyu marriage: beliefs and practices. Discussion paper number 17, Institute of African studies.University of Nairobi.Retrieved from http//:wwwerepository.uonbi.ac.ke.

Mutongi,K.(1999), "Worries of the Heart:Widowed Mothers, Daughters and Masculinities in Maragoli, Western Kenya, 1940-1960" In Journal of African History, 40. London:Cambridge University Press.

Okuro,S..O.(2002),The impact of colonial socio-economic policies and practices of female-headed households in Kenya: The case of Kombewa Division, Kisumu District 1894-1963.M.A Thesis., Kenyatta University.

Shorter, A.(1975), African Culture and Christian churches. Nairobi: Geoffrey

Strayer, R.W. (1978), The Making of Mission Communities in East Africa. London: Heinemann.

Structural functionalism.(2017), Retrieved from https://en.m.wikibooks.org

Webourn, F.B.(1965),East African Christians. London: Oxford University Press.

Wipper,A. Rural Rebels: A study of two protest movements in Kenya. London: Oxford University press. 